\title{
Effect of fertilizer dose on the performance of spring cereals
}

\author{
Zar Muhammad ${ }^{1}$, Gulzar Ahmad ${ }^{1}$, Babar Iqbal ${ }^{2 *}$, Subhanullah $^{1}$, Riaz \\ Muhammad Khan ${ }^{1}$, Abdul Bari ${ }^{1}$ and Shahen Shah ${ }^{2}$ \\ 1. Cereal Crops Research Institute (CCRI), Pirsabak Nowshera, KP-Pakistan \\ 2. Department of Agronomy, University of Agriculture, Peshawar, Pakistan \\ *Corresponding author's email: agronomist19388@yahoo.com \\ Citation \\ Zar Muhammad, Gulzar Ahmad, Babar Iqbal, Subhanullah, Riaz Muhammad Khan, Abdul Bari and Shahen Shah. \\ Effect of fertilizer dose on the performance of spring cereals. Pure and Applied Biology. Vol. 5, Issue 3, pp458-463. \\ http://dx.doi.org/10.19045/bspab.2016.50059
}

\begin{tabular}{llll}
\hline \hline Received: 28/11/2015 & Revised: 10/05/2016 & Accepted: 26/05/2016 & Online First: 28/05/2016 \\
\hline
\end{tabular}

\section{Abstract}

In country like Pakistan where population is growing at an alarming rate, food shortage is the top challenge for researchers. To contribute to this effort, field trials entitled "Effect of fertilizer dose on the performance of spring cereals" were conducted at Cereal Crops Research Institute Pirsabak Nowshehra, Khyber Pakhtunkhwa, Pakistan during 2010-2011. The experiment was laid out in RCB design with split plot arrangement replicated three times, with plot size $5 \mathrm{X} 1.8 \mathrm{~m}$, having 6 rows $30 \mathrm{~cm}$ apart. Fertilizer doses were allotted to main while cereal species were allotted to subplots. Fertilizer dose, cereal species and their interaction had significantly affected cereal performance. Application of 60:30:30 and 120:60:60 (N:P:K kg ha $\left.{ }^{-1}\right)$ significantly affected plant height and phenology of cereals than no NPK. Application of 60:30:30 and 120:60:60 produced $55 \%$ and $62 \%$ more grain yield respectively than no NPK. Wheat, triticale and oat phenology was significantly delayed, oat and triticale produced taller plants than wheat and barley. Triticale yield was significantly higher than barley, wheat and oat. In case of interactions triticale with 120:60:60 NPK took more days to heading (131) and physiological maturity (168), while barley took less days to heading (109) and physiological maturity with no NPK. Significantly taller plants were produced by oat $(129 \mathrm{~cm})$ at 120:60:60 while barley produced dwarf plants $(73 \mathrm{~cm})$ with no NPK. In case of grain yield, triticale produced more yield $\left(5275 \mathrm{~kg} \mathrm{ha}^{-1}\right)$ with 60:30:30 while oat gave lowest yield $\left(2433 \mathrm{~kg} \mathrm{ha}^{-1}\right)$ with no NPK. It is concluded that triticale and barley performed well on less fertile soil than wheat and oat. For optimum production, 60:30:30 and 120:60:60 (N: P: K $\mathrm{kg} \mathrm{ha}^{-1}$ ) are recommended for barley/triticale and wheat/oat respectively, in conditions similar to Nowshehra.

Key words: Barley; Fertilizer dose; Performance; Triticale; Yield

Introduction

Spring cereals like wheat, barley, triticale and oat are used as human food and livestock feed since ancient times. Spring Wheat (Triticum aestivum L.) is the major staple food crop of Pakistan. It occupies $70 \%$ of the Rabi and $37 \%$ of the total cropping area in the country. Per capita consumption of wheat in Pakistan is the highest in the world (135 kg year $\left.{ }^{-1}\right)$, which contributes $72 \%$ of the total calories intake (Annual report CCRI 2010-11). In Pakistan in general and in KPK in particular, low 
productivity is mainly correlated to low soil fertility.

Many researches have been conducted on crop nutrients management and optimization. These studies for example [1-3] have revealed the significant importance of fertilizer optimization for spring cereals. However there is need to work out the combine effect of NPK on combination of various spring cereals.

Keeping in view the importance of combine fertilizer optimization for spring cereals, the present study was conducted to evaluate the response of spring cereals to various levels of NPK.

\section{Materials and methods}

Field trials were conducted at Cereal Crops Research Institute Pirsabak, Nowshera during 2010-11 in randomized complete block design with split plot arrangement, having three replications. Fertilizer levels of N: P: K (0:0:0, 60:30:30 and 120:60:60 kg ha- ${ }^{1}$ ) were allotted to main plot while cereal species (Wheat, triticale, barley and oat) were applied to sub plots. Plot size was $5 \times 3.6 \mathrm{~m}$ $\left(18 \mathrm{~m}^{2}\right)$, having 6 rows, $30 \mathrm{~cm}$ apart. Sowing was done on $25^{\text {th }}$ of November 2010. Half of the nitrogen was applied at sowing while half of nitrogen was applied after 45 days of sowing. All of the Phosphorus and potash were applied at sowing time. Agronomic practices were conducted as per protocol for all the crop species. Data were recorded on days to heading, days to physiological maturity, plant height $(\mathrm{cm})$, grain yield $(\mathrm{kg}$ $\left.\mathrm{ha}^{-1}\right)$. Data recorded for various parameters were individually subjected to the ANOVA and LSD using MS Excel program.

\section{Results and Discussion}

Days to heading

Data regarding days to heading is presented in table 1. Data indicates that fertilizer levels, cereal species and their interaction significantly $(\mathrm{P}<0.05)$ affected days to heading. Significantly more days (125) were observed for 120:60:60 (N: P: K kg ha- ${ }^{1}$ ) while less days (118) were recorded for no NPK application. Significantly more days (126) were taken by oat while least days to heading (111) were observed for barley. In case of fertilizer and cereal species interaction, more days to heading (131) were recorded when 120:60:60 (N: P: K kg ha- ${ }^{1}$ ) was applied while least days to heading (109) were taken by barley without NPK application. Delay in days to heading with increase in fertilizer dose might be due to more nutrients availability specially nitrogen which prolongs vegetation growth period [3]. Potassium and phosphorus fertilization have significantly improved days to flowering, days to maturity, grains spike ${ }^{-1}, 1000$ grain weight and grain yield as compared control Amanullah and Khan, 2010 [4]. Significant effect of cereal species might be due to difference in genetic potential [5] of different species which determines the length of vegetative and reproductive stages.

Table 1. Days to heading of spring cereals as affected by different NPK levels

\begin{tabular}{|l|l|l|l|l|l|}
\hline NPK Levels & \multicolumn{5}{|c|}{ Cereal Species } \\
\cline { 2 - 7 } & Wheat & Triticale & Barley & Oat & Mean \\
\hline $\mathbf{0 : 0 : 0}$ & $121 \mathrm{~d}$ & $119 \mathrm{e}$ & $109 \mathrm{~h}$ & $122 \mathrm{~d}$ & $118 \mathrm{c}$ \\
\hline $\mathbf{6 0 : 3 0 : 3 0}$ & $124 \mathrm{c}$ & $124 \mathrm{c}$ & $111 \mathrm{~g}$ & $126 \mathrm{~b}$ & $121 \mathrm{~b}$ \\
\hline $\mathbf{1 2 0 : 6 0 : 6 0}$ & $127 \mathrm{~b}$ & $126 \mathrm{~b}$ & $114 \mathrm{f}$ & $131 \mathrm{a}$ & $125 \mathrm{a}$ \\
\hline Mean & $124 \mathrm{~b}$ & $123 \mathrm{c}$ & $111 \mathrm{~d}$ & $126 \mathrm{a}$ & \\
\hline $\begin{array}{l}\text { LSD for NPK Levels }= \\
\text { LSD for Cereal Species }=\end{array}$ & 0.55 & & & \\
LSD for Interaction $=$ & 1.63 & & & \\
\end{tabular}




\section{Days to physiological maturity}

Data recorded on days to physiological maturity is given in table 2. Based on the data it is revealed that fertilizer levels, cereal species and interaction of fertilizer levels and cereal species had significantly affected days to physiological maturity. Significantly $(\mathrm{P}<0.05)$ more days (161) were observed when 120:60:60 (N: P: K kg ha- ${ }^{1}$ ) was applied followed by 60:30:30 (N: P: K kg ha$\left.{ }^{1}\right)$ with 157 days. Lowest days (152) were recorded in plots without NPK application. In case of cereal species, more days to physiological maturity (163) were observed for oat while least (150 days) were recorded for barley. Regarding interaction, more days to physiological maturity (168) were recorded for oat when 120:60:60 (N: P: K kg ha- $^{1}$ ) was applied while least days (147) were taken by barley when no NPK was applied. Delay in physiological maturity with increase in fertilizer level might be the result of more nutrients availability, especially nitrogen, which enhances the vegetative growth period and hence prolongs plant life cycle [3]. Potassium and phosphorus fertilization have significantly improved days to flowering, days to maturity, grains spike ${ }^{-1}, 1000$ grain weight and grain yield as compared control Amanullah and Khan, 2010 [4]. Significant effect of cereal species might be due to difference in genetic potential [5] of different species which determines the length of vegetative and reproductive stages.

Table 2. Days to physiological maturity of spring cereals as affected by different NPK levels

\begin{tabular}{|l|l|l|l|l|l|}
\hline \multirow{2}{*}{ NPK levels } & \multicolumn{5}{|c|}{ Cereal Species } \\
\cline { 2 - 6 } & Wheat & Triticale & Barley & Oat & Mean \\
\hline $\mathbf{0 : 0 : 0}$ & $155 \mathrm{~d}$ & $154 \mathrm{de}$ & $147 \mathrm{~g}$ & $156 \mathrm{~d}$ & $152 \mathrm{c}$ \\
\hline $\mathbf{6 0 : 3 0 : 3 0}$ & $159 \mathrm{c}$ & $155 \mathrm{~d}$ & $150 \mathrm{f}$ & $165 \mathrm{~b}$ & $157 \mathrm{~b}$ \\
\hline $\mathbf{1 2 0 : 6 0 : 6 0}$ & $165 \mathrm{~b}$ & $158 \mathrm{c}$ & $154 \mathrm{de}$ & $168 \mathrm{a}$ & $161 \mathrm{a}$ \\
\hline Mean & $159 \mathrm{~b}$ & $156 \mathrm{c}$ & $150 \mathrm{~d}$ & $163 \mathrm{a}$ & \\
LSD for fertilizers & $=1.57$ & & \\
LSD for Cereal Species & $=$ & 1.10 &
\end{tabular}

Plant height (cm)

As shown table 3, fertilizer levels, cereal species and their interaction have significantly $(\mathrm{P}<0.05)$ affected plant height. Fertilizer application at 60:30:30 and 120:60:60 (N: P: K kg ha ${ }^{-1}$ ) increased plant height by $7 \%$ and $14 \%$ as compared to no application of fertilizer. This increase may be the result of nutrients availability specially nitrogen which enhanced plant growth and hence plant height [6]. Oat and triticale produced significantly taller plants (119 and $112 \mathrm{~cm})$ than wheat and barley (100 and $76 \mathrm{~cm})$. Difference in plant height of different cereal species might be due to difference in genetic potential for plant height. This statement is supported by the findings of Jorgensen et al. [1] who reported that triticale and rye had a higher total dry matter yield than wheat, even at lower inputs of $\mathrm{N}$ fertilizer. This finding is also supported by the research work of Awasthi \& Bhan (1994) [7] who noticed increased in leaf area and plant height with increase in fertilizer rate. In case of interaction plant height was significantly higher for oat $(129 \mathrm{~cm})$ at 120:60:60 (N: P: K kg ha ${ }^{-1}$ ) while it was lowest $(73 \mathrm{~cm})$ for barley without fertilizer. A dose of $70 \mathrm{~kg} \mathrm{~N}$ significantly increased the yield of all cereal species, but yield increases at $140 \mathrm{~kg} \mathrm{~N}$ were not always significant when compared with $70 \mathrm{~kg} \mathrm{~N}$ [8]. 
Table 3. Plant height (cm) of spring cereals as affected by different NPK levels

\begin{tabular}{|l|l|l|l|l|l|}
\hline \multirow{2}{*}{ NPK levels } & \multicolumn{5}{|c|}{ Cereal Species } \\
\cline { 2 - 6 } & Wheat & Triticale & Barley & Oat & Mean \\
\hline 0:0:0 & $95 \mathrm{~g}$ & $105 \mathrm{e}$ & $73 \mathrm{j}$ & $106 \mathrm{e}$ & $95 \mathrm{c}$ \\
\hline $\mathbf{6 0 : 3 0 : 3 0}$ & $100 \mathrm{f}$ & $112 \mathrm{~d}$ & $76 \mathrm{i}$ & $123 \mathrm{~b}$ & $102 \mathrm{~b}$ \\
\hline $\mathbf{1 2 0 : 6 0 : 6 0}$ & $104 \mathrm{e}$ & $118 \mathrm{c}$ & $79 \mathrm{~h}$ & $129 \mathrm{a}$ & $108 \mathrm{a}$ \\
\hline Mean & $100 \mathrm{c}$ & $112 \mathrm{~b}$ & $76 \mathrm{~d}$ & $119 \mathrm{a}$ & \\
LSD for fertilizers & $=1.46$ \\
LSD for Cereal Species & $=1.36$ \\
LSD for Interaction & $=\quad 2.36$ &
\end{tabular}

\section{Grain yield $\left(\mathrm{kg} \mathrm{ha}^{-1}\right)$}

Fig. 1 is the graphical representation of grain yield trend. It is clear from the graph that both, fertilizer levels and cereal species as well as their interaction had significantly affected grain yield. Application of 60:30:30 and 120:60:60 (N: P: K kg ha- ${ }^{-1}$ ) produced $55 \%$ and $62 \%$ more grain yield respectively than no NPK application. This increase in grain yield at higher levels of fertilizers may be the consequence of more nutrients availability which resulted in more number of spikes $\mathrm{m}^{-2}$, spike length and number of grains spike $^{-1}$ [2]. In addition, more dry matter and $\mathrm{N}$ are accumulated at grain filling stage by high $\mathrm{N}$ demanding crops due to larger canopy than low $\mathrm{N}$ demanding, resulting in more grain yield and protein content at harvest. The number of grains per unit area and grain yield was closely correlated with dry matter content and $\mathrm{N}$ application at anthesis [9]. Wheat crop produced on average 1.59 times more grain yield and 1.77 times more straw yield with the application $\mathrm{N}$ fertilizer as compared to control [10]. The grain yield of wheat was improved with $\mathrm{N}$ fertilization due to its effect on yield components, phenology and leaf characteristics. Crop growth and senescence rate are dependent on $\mathrm{N}$ availability, as the number of grains set per unit area and grain size. Stronger sink (more grains per unit area and per spike) was developed with the improved availability of $\mathrm{N}$ [11]. Increase in grain yield with increase in fertilizer levels may be attributed to more vigorous plants which resulted in more productive plants $\mathrm{m}^{-2}$, more thousand grain yield and hence more grain yield. Grain yield and crude protein concentration were increased by fertilizer $\mathrm{N}$ compared with the plots without $\mathrm{N}$ fertilizer [12]. In case of cereal species, triticale yield was significantly higher (4293 kg ha-1) than barley, wheat and oat $(3355,3165$ and 2794 $\mathrm{kg} \mathrm{ha}^{-1}$ ) respectively. It was observed that 60:30:30 (N: P: K kg ha- ${ }^{-}$) was optimum dose for barley and triticale. Increase in fertilizer beyond this level was not positively correlated with grain yield. This shows that barley and triticale perform well on low fertile soil than oat and wheat. Decrease in grain yield with increase in fertilizer might be due to lodging which results in nonproductive tillers and decrease in thousand grain weight. The type and amount of $\mathrm{N}$ fertilizer applied at all three locations mainly influenced dry matter content and grain $\mathrm{N}$ status [13]. In autumn season sowing, the long vegetative duration resulted in more dry matter content and $\mathrm{N}$ at anthesis as compared winter sowing, which resulted in more final grain yield [9]. 


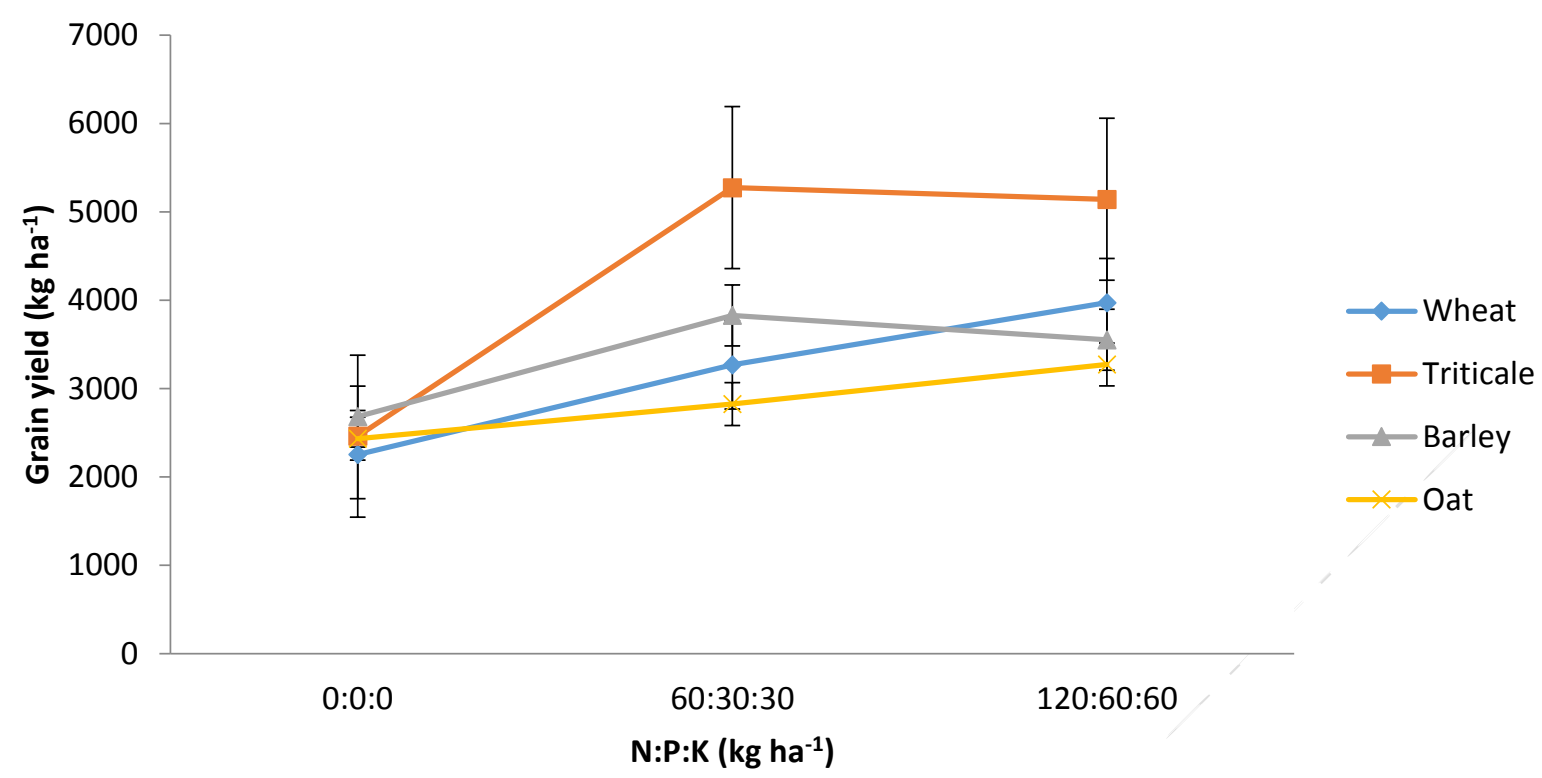

Figure 1. Grain yield $\left(\mathrm{kg} \mathrm{ha}^{-1}\right)$ of spring cereals as affected by different NPK levels

\section{Conclusions \& recommendations}

It is concluded that triticale and barley performed well on less fertile soil than wheat and oat. For optimum production, 60:30:30 and 120:60:60 (N: P: K kg ha-1) are recommended for barley/triticale and wheat/oat respectively, in conditions similar to Nowshehra.

\section{Authors' contributions}

Conceived and designed the experiments: $\mathrm{Z}$ Muhammad \& G Ahmad, Performed the experiments: Z Muhammad \& B Iqbal, Analyzed the data: $\mathrm{Z}$ Muhammad \& G Ahmad, Contributed reagents/ materials/ analysis tools: S Ullah, RM Khan, A Bari \& S Shah, Wrote the paper: Z Muhammad \& B Iqbal.

\section{Acknowledgement}

Financial support by WPEP for conducting this project is highly acknowledged.

\section{References}

1. Jorgensen JR, Deleuran LC, Wollenweber B (2007). Prospects of whole grain crops of wheat, rye and triticale under different fertilizer regimes for energy production, Biomass and Bioenergy 31(5):308-317.
2. Turk MA, Tawaha AM, Samarah N \& Allataffeh N (2003). The response of barley to nitrogen fertilizer application and weed control methods. Pak J Agron 2(2): 101-108.

3. Khan A, Khan M \& M. Azam (2000). Agro-economic triats of dryland barley as influenced by NP fertilizer application. Pak J Biol Sci 3(10): 16371638.

4. Amanullah \& Khan MW (2010). Interactive Effects of Potassium and Phosphorus on Phenology and Grain Yield of Sunflower in Northwest Pakistan. Pedosphere 20(5):674-680.

5. Miralles DJ, Ferro BC, Slafer GA (2001). Developmental responses to sowing date in wheat, barley and rapeseed. Field Crops 71(3): 211-223.

6. Awasthi UD \& Bhan S (1996). Effect of nitrogen levels on wheat and barley varieties under moisture scarce conditions. 11(4): 245-253.

7. Awasthi UD \& Bhan S (1994). Physiological response of barley genotypes to nitrogen levels under moisture scarce conditions on light 
textured soils of central Uttar Pardesh. Indian J pl Phydio 37(1):32-34.

8. Lewandowski I \& Kauter D (2003). The influence of nitrogen fertilizer on the yield and combustion quality of whole grain crops for solid fuel use. Industrial Crops and Products 17(2):103-117.

9. Ferrise R, Triossi A, Stratonovitch P, Bindi M \& Martre P (2010). Sowing date and nitrogen fertilisation effects on dry matter and nitrogen dynamics for durum wheat: An experimental and simulation study. Field Crop 117(2-3): 245-257.

10. Bakht J, Shafi M, Jan MT \& Shah Z (2009). Influence of crop residue management, cropping system and $\mathrm{N}$ fertilizer on soil and $\mathrm{C}$ dynamics and sustainable wheat production. Soil and tillage 104(2): 233-240.
11. Fois S, Motzo R \& Giunta F (2009). The effect of nitrogenous fertiliser application on leaf traits in durum wheat in relation to grain yield and development. Field Crop 110(1, 5): 6975.

12. Mengel K, Hütsch B \& Kan Y (2006). Nitrogen fertilizer application rates on cereal crops according to available mineral and organic soil nitrogen. European J Agron 24(4): 343-348.

13. Doltra J, Lægdsmand $M$ \& Olesen JE (2011). Cereal yield and quality as affected by nitrogen availability in organic and conventional arable crop rotations: A combined modeling and experimental approach. European $J$ Agron. 34(2): 83-95. 